\title{
Keratinocyte growth factor in the rat ventral prostate: androgen-independent expression
}

\author{
J A Nemeth, D J Zelner, S Lang and C Lee
}

Department of Urology, Northwestern University Medical School, Chicago, Illinois 60611, USA

(Requests for offprints should be addressed to C Lee, Department of Urology, Tarry 11-715, Northwestern University Medical School, 303 E Chicago Avenue, Chicago, Illinois 60611, USA)

\begin{abstract}
Keratinocyte growth factor (KGF/FGF-7) is a stromally derived factor which exerts proliferative and differentiating effects on a variety of epithelial cells. Results of recent studies utilizing in vitro methods such as tissue culture and organ culture have suggested that KGF may act as a paracrine mediator of androgen-induced growth and development of the prostate and seminal vesicle. We undertook the present study to determine the distribution of KGF in relation to the functional regions of the rat prostatic ductal system, and whether KGF expression is influenced by androgen in vivo. Immunohistochemical staining revealed KGF to be present in the stroma throughout the prostate, regardless of the functional region, and staining for KGF remained high through 21 days post-castration. Message for KGF could also be detected by
\end{abstract}

reverse transcriptase-PCR analysis of prostate stromal cells isolated from 4- and 21-day castrated animals, and no gross change in message level was observed following castration. Furthermore, no significant change in either stromal staining or message for KGF was observed in newborn rat prostates 10 days after castration, suggesting a similar regulatory mechanism for KGF in the adult and immature prostate. Epithelial staining for KGF decreased following castration, and greatly increased upon androgen replacement, possibly indicating a change in KGF internalization. These observations suggest that the presence of KGF protein is not related to functional differences in the prostate epithelium, and that expression of KGF in vivo is not greatly influenced by androgen.

Journal of Endocrinology (1998) 156, 115-125

\section{Introduction}

The prostate is absolutely dependent on an adequate supply of circulating androgen for normal growth and maintenance of differentiated function. In the adult prostate, the presence of androgen also serves to maintain a homeostatic balance between cell proliferation and cell death, resulting in no net change in prostate size (Isaacs 1984). Results of our previous studies have shown that epithelial cell proliferation, differentiation and cell death take place in specific regions of the prostatic duct in normal rats (Lee et al. 1990). Cells at the distal tips of the ducts are capable of proliferation, as evidenced by DNA synthesis (Sugimura et al. 1986), the presence of apical nuclei (Lee et al. 1994) and occasional mitotic figures (Lee et al. 1990). Cells lining the intermediate ductal region are in a differentiated state and actively secrete prostate-specific proteins. Many epithelial cells in the proximal region, near the urethra, are undergoing active cell death as determined by high levels of cathepsin D (Lee et al. 1990) and the presence of apoptotic bodies (Kerr \& Searle 1973). This observed regional variation in epithelial response to a homogeneous level of circulating androgen has provided us with an opportunity to study the mechanisms that govern androgen action in the prostate.

Normal prostatic growth, development and functional activity are clearly dependent upon interactions between the stroma and epithelium (Tenniswood 1986, Chang \& Chung 1989), and numerous studies have suggested that the epithelial response to androgen is mediated indirectly through soluble factors produced by the stroma (McKeehan et al. 1984). The work of Cunha \& Chung (1981) and Cunha et al. (1981, 1983) has provided further insights into the indirect nature of androgen action in the prostate. Through the use of elegant tissue recombination techniques, it was demonstrated that the prostatic stroma or mesenchyme is the target and mediator of androgeninduced glandular morphogenesis and epithelial cell growth. Further study into the relationship between androgen and stroma has provided clues as to possible mechanisms behind the regional variation in epithelial function along the prostatic duct. Prins et al. (1991) have demonstrated differences in androgen receptor expression between various cell types within the stroma, and hypothesized that variations in the proportion of stromal cell types along the duct could be involved in mediating epithelial activity (Prins et al. 1992). Recently we described 
region-specific variations in the distribution of smooth muscle and fibrous tissue along the prostatic duct (Nemeth \& Lee 1996). The distal tips of the ducts were surrounded mainly by fibrous tissue. Smooth muscle became more abundant in the intermediate region, and multiple layers of smooth muscle cells were found surrounding the proximal ducts. Thus it is possible that the regional variation in epithelial response to androgen may result from differences in the ratio of smooth muscle and fibrous tissue, and their respective secretory products, along the prostatic duct.

Keratinocyte growth factor (KGF/FGF-7) is a member of the fibroblast growth factor (FGF) family which has begun to receive attention for its possible role in prostate biology. Observations that KGF is only produced by cells of mesenchymal origin and acts specifically on epithelialtype cells have established a unique role for it as a mediator of stromal to epithelial communication (see Rubin et al. (1995) for a review). Prostate stromal cells in culture have been shown to secrete KGF (Yan et al. 1992). Likewise, the FGF receptor 2 containing the IIIb exon, which imparts specificity for KGF (Miki et al. 1992), has been demonstrated in prostate epithelial cells (Story et al. 1994). The recent finding that androgen can enhance expression of KGF by prostatic fibroblasts in culture (Yan et al. 1992) suggested that KGF may be a mediator of androgen action in the prostate. Further support for the importance of KGF in the growth and development of the urogenital system has come from organ culture studies in which the androgen-induced growth and branching of newborn prostate (Sugimura et al. 1996) or seminal vesicle (Alarid et al. 1994) could be blocked by neutralization of KGF activity.

To define more precisely the role of KGF in the regulation of prostate growth, we have examined its localization with respect to the functional regions of the rat prostatic ductal system, and tested whether its expression is under androgen control in the prostate in situ. By immunohistochemical analysis, KGF protein was found to be present in the stroma throughout the ductal system, independent of the functional region. Using a combination of immunohistochemistry and semiquantitative reverse transcriptase (RT)-PCR, we also found that KGF was expressed constitutively, independent of androgen status, in both the adult and newborn rat prostate.

\section{Materials and Methods}

\section{Antiserum preparation and Western blot analysis}

Rabbit antiserum to KGF was produced by Research Genetics, Inc. (Huntsville, AL, USA) against a synthetic peptide corresponding to the $16 \mathrm{C}$-terminal amino acids of rat KGF (TKKEQKTAHFLPMAIT). Serum from the 10-week bleed was used for all experiments. To control for antibody cross-reactivity, Western blot analysis was performed on purified samples of commercially prepared members of the FGF family (FGF-1, -2, -4, -5, -6, -7; R\&D Systems, Minneapolis, MN, USA). Aliquots of $100 \mathrm{ng}$ of each protein were reduced by heating in the presence of $5 \% \beta$-mercaptoethanol, separated by SDS/ PAGE (Laemmli 1970), and blotted to nitrocellulose. Alternatively, samples of rat prostate tissue were homogenized in PBS containing $0.1 \%$ SDS, $10 \mu \mathrm{M}$ aprotinin and $1 \mathrm{~mm}$ phenylmethylsulfonyl fluoride, and aliquots of $100 \mu \mathrm{g}$ were reduced by heating with $5 \% \quad \beta$-mercaptoethanol and separated as described above. The membrane was blocked overnight in PBS containing 3\% BSA and $0.05 \%$ Tween 20. After blocking, the membrane was incubated at $4{ }^{\circ} \mathrm{C}$ overnight with a 1:200 dilution of either whole rabbit anti-KGF or preimmune rabbit serum in $0 \cdot 05 \%$ Tween/PBS, followed by a $2 \mathrm{~h}$ incubation with alkaline phosphatase-conjugated goat anti-rabbit antiserum (1:6000; Bio-Rad, Hercules, CA, USA). Immunoreactive bands were visualized using NBT/BCIP as a substrate (Boehringer-Mannheim Biochemicals, Indianapolis, IN, USA).

\section{Animals}

Male Sprague-Dawley rats $(275-300 \mathrm{~g})$ were purchased from Harlan Industries (Cumberland, IN, USA) and maintained according to the NIH standards established in the Guidelines for the Care and Use of Experimental Animals. Castrations were performed via scrotal incision while under anesthesia with methoxyflurane vapor. For androgen replacement experiments, 21-day castrated rats were anesthetized, and $2 \mathrm{~cm}$ silastic tubes (internal diameter $1.575 \mathrm{~mm}$; outer diameter $3.175 \mathrm{~mm}$; DowCorning, Midland, MI, USA) containing crystalline dihydrotestosterone (DHT; Sigma, St Louis, MO, USA) were implanted subcutaneously. Before prostate harvesting, animals were decapitated while under anesthesia with methoxyflurane vapor. The ventral prostate lobes were carefully removed, weighed and fixed in Bouin's fluid for $2 \mathrm{~h}$. After embedment in paraffin, $4 \mu \mathrm{m}$ sections were cut and subjected to immunohistochemical staining for KGF. For consistency, all tissues were harvested and processed at the same time. For studies on neonatal prostate, pregnant female rats were purchased and maintained as above. On day 4 after birth, male pups were castrated via a small perineal incision while under anesthesia with methoxyflurane vapor. On day 14 after birth, prostates were harvested from the pups as above, weighed and fixed overnight in Optiprobe (Oncor, Gaithersburg, MD, USA). After embedment in paraffin, $4 \mu \mathrm{m}$ sections were cut and subjected to immunohistochemical staining for KGF.

\section{Immunohistochemistry}

Colorimetric staining for KGF was carried out using a commercial kit (ABC Elite kit; Vector Laboratories, Burlingame, CA, USA). Briefly, histological sections were 
deparaffinized, rehydrated and treated with $0 \cdot 3 \%$ hydrogen peroxide for $30 \mathrm{~min}$ to inactivate endogenous peroxidase. Normal goat serum was used to block nonspecific binding to sections. In a humidified chamber, Bouin's-fixed sections were incubated with whole antiserum to KGF at a dilution of $1: 2000$ for $18 \mathrm{~h}$ at $4{ }^{\circ} \mathrm{C}$, while KGF-control sections were incubated with preimmune rabbit serum at the same dilution. An additional control was included to ensure the specificity of KGF staining. Aliquots of diluted KGF antiserum were preincubated with $100 \mu \mathrm{g} / \mathrm{ml}$ recombinant human KGF (R\&D Systems) for $1 \mathrm{~h}$ at room temperature, then applied to tissue sections. Positive reaction sites were detected by subsequent incubation with biotinylated secondary antiserum, avidin-biotin-horseradish peroxidase complex and diaminobenzidine tetrahydrochloride. Nuclei were counterstained with Gill's hematoxylin.

Photomicrographs were taken through an Olympus BH2 microscope (Olympus Camera Co., Woodbury, NY, USA) equipped with a camera. Color prints of colorimetric staining were developed from Ektachrome 64T films followed by photoprocessing (Eastman Kodak, Rochester, NY, USA).

\section{Tissue dissociation and Percoll step-gradient centrifugation}

In preparation for RT-PCR experiments, adult rat ventral prostates were harvested, placed in a sterile Petri dish and minced into small pieces (approximately $1 \mathrm{~mm}^{3}$ ) with curved scissors in a laminar flow hood. The minced tissues were transferred to a $50 \mathrm{ml}$ polypropylene tube containing $40 \mathrm{ml} 1.0 \mathrm{~mm}$ dithiothreitol (Bio-Rad Laboratories,

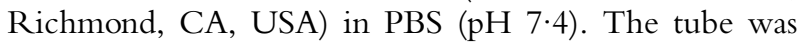
placed on a rotating agitator for $30 \mathrm{~min}$ at $37^{\circ} \mathrm{C}$. The tissues were allowed to settle briefly, the supernatant was discarded, and $10 \mathrm{ml}$ of a dissociation solution containing 1\% DNase type I (Sigma), 0.28\% collagenase type I (Sigma) and 10\% fetal bovine serum (Gibco, Gaithersburg, MD, USA) in RPMI 1640 (Gibco) were added. The tube was then rotated for $30 \mathrm{~min}$ at $37^{\circ} \mathrm{C}$. After a $5 \mathrm{~min}$ settling period, the supernatant was collected and reserved, and the remaining tissue pieces were subjected to a second digestion as described above. The first and second dissociation supernatants were pooled and passed through a series of three tissue sieves with pore sizes ranging from 230 to $46 \mu \mathrm{m}$ (Bellco Glass Co., Vineland, NJ, USA). The cells were then rinsed twice in RPMI 1640 containing $10 \%$ fetal bovine serum, passed through a 25 gauge needle, and counted in a Coulter Counter (Coulter Electronics, Hialeah, FL, USA).

Separation of epithelial and stromal cell fractions was performed by a method similar to that of Montpetit \& Tenniswood (1989). A 20\% stock of isoionic Percoll (Sigma) was prepared by the addition of 1 volume $10 \times$ PBS to 9 volumes Percoll. This stock was then diluted with $1 \times$ PBS to make $10 \%$ (1 volume stock to 1 volume PBS) and 5\% (1 volume stock to 3 volumes PBS) Percoll. The Percoll solutions were layered in $50 \mathrm{ml}$ polypropylene tubes, starting with $10 \mathrm{ml}$ of $10 \%$, then $10 \mathrm{ml}$ of $5 \%$ Percoll. Aliquots $(5 \mathrm{ml})$ of the dissociated cell suspension were layered on top of the $5 \%$ Percoll, and the gradient tubes were centrifuged at room temperature for $30 \mathrm{~min}$ at $750 \boldsymbol{g}$ (Beckman TJ-6 centrifuge; 2000 r.p.m.). The cells were collected by careful removal of each Percoll layer and collection of the density interfaces. The cells were washed 3 times with PBS at $4{ }^{\circ} \mathrm{C}$, and cell viability was determined by trypan blue exclusion. Washed cells were pelleted and frozen immediately in liquid nitrogen, and stored at $-80{ }^{\circ} \mathrm{C}$ until use for RNA sample preparation.

To assess the purity and identity of each cell fraction, aliquots of the stromal and epithelial fractions were adhered to slides by cytocentrifugation, fixed for $5 \mathrm{~min}$ in methanol and stained as described above using antisera to basal cell cytokeratin 5 (ab 903; Enzo Diagnostics, New York, NY, USA; 1:5 dilution) and luminal cell cytokeratin 18 ( $\alpha$-CKSE, number RPN.1160; Amersham, Arlington Heights, IL, USA). Percentages of cytokeratin-positive and -negative cells for each fraction were determined visually.

\section{$R N A$ isolation and $R T-P C R$}

Whole RNA was prepared from either isolated epithelial and stromal cell fractions from adult prostates, or whole neonatal prostates, using Trizol reagent following the manufacturer's recommended protocol (Gibco). RT-PCR was performed on $750 \mathrm{ng}$ samples of RNA using a Gene Amp RNA PCR kit (Perkin-Elmer, Norwalk, CT, USA) following the manufacturer's suggested protocol for singletube RT-PCR. The respective $5^{\prime}$ and $3^{\prime}$ primers for rat KGF spanned nucleotides 200-223 (CTTGCAATGACA TGAGTCCAGAGC) and 592-616 (CCCCTCCGCTG TGTGTCCATTTAGC) of the KGF cDNA sequence reported by Yan et al. (1992). Separate reactions were also performed in parallel using primers for the rat $\beta$-actin cDNA (Clontech, Palo Alto, CA, USA) for use in comparative measurements. The conditions for reverse transcription using the $3^{\prime}$ primer were $45^{\circ} \mathrm{C}$ for $15 \mathrm{~min}$, $99^{\circ} \mathrm{C}$ for $5 \mathrm{~min}$ and $5{ }^{\circ} \mathrm{C}$ for $5 \mathrm{~min}$. After reverse transcription, PCR was performed using the following conditions: $94{ }^{\circ} \mathrm{C}$ for $1 \mathrm{~min}, 60^{\circ} \mathrm{C}$ for $1 \mathrm{~min}, 72{ }^{\circ} \mathrm{C}$ for $2 \mathrm{~min}$, for 26 cycles, followed by $10 \mathrm{~min}$ at $72{ }^{\circ} \mathrm{C}$. The authenticity of the KGF product was confirmed by diagnostic restriction digestion with BamHI (Promega, Madison, WI, USA). As an additional control to detect possible contamination of RNA samples by genomic DNA, duplicate reactions were performed omitting the reverse transcriptase. PCR products were separated by electrophoresis and visualized with ethidium bromide. 


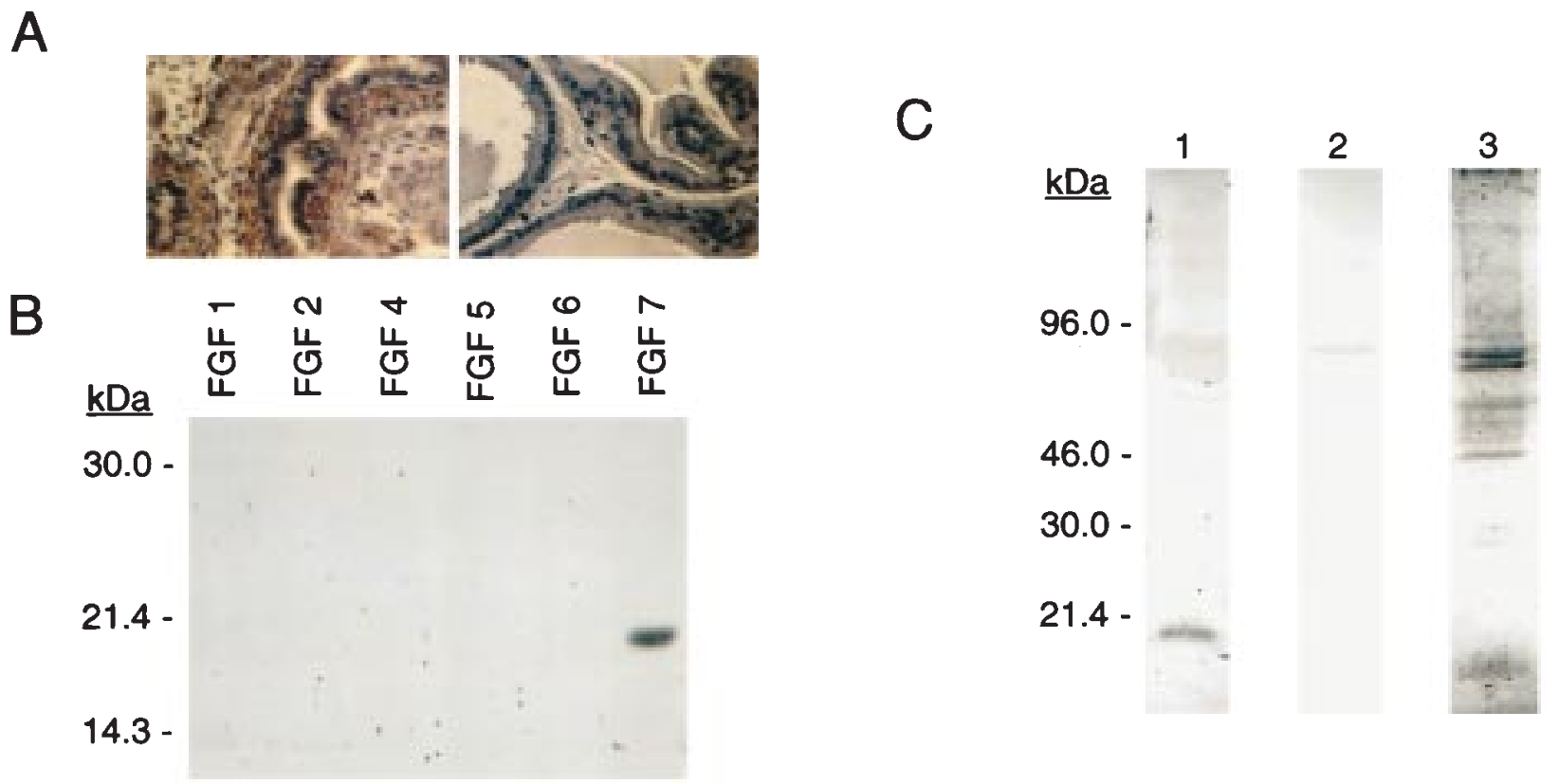

Figure 1 Specificity of antiserum to KGF synthetic peptide. A, Sections of rat ventral prostate were incubated with anti-KGF serum alone (left panel) or with antiserum that had been preincubated with $100 \mu \mathrm{g} / \mathrm{ml}$ recombinant human KGF (right panel). Immunoreactivity is indicated by brown staining. B, Samples (100 ng) of recombinant human FGF-1, -2, -4, -5, -6, and -7 were separated by SDS/PAGE, blotted and detected using anti-KGF serum. C, Samples $(100 \mu \mathrm{g})$ of prostate homogenate were separated by SDS/PAGE, blotted and detected with anti-KGF serum (lane 1), preimmune rabbit serum (lane 2) or amido black for total protein detection.

Densitometric measurements of band intensity were performed on black and white photographs (PDI Discovery Series, Huntington Station, NY, USA).

For the stromal-cell samples, comparative measurement of KGF expression by RT-PCR was performed essentially as described by Camp et al. (1991). Briefly, the linear range of the PCR was determined by performing RT-PCR as described above and stopping the amplification of replicate samples at regular intervals. We chose to use 26 cycles for our measurements, as this was within the linear range of amplification for KGF and $\beta$-actin (data not shown). Band intensities for each sample were then normalized to the corresponding $\beta$-actin band intensity, and values were expressed as percentage of uncastrated (day 0) controls. Statistical analysis was performed using the two-tailed Student's $t$-test. Analysis of epithelial RNA samples was also performed to confirm a lack of KGF expression (data not shown).

\section{Results}

Specificity of KGF antiserum

Before immunohistochemical staining, the specificity of our rabbit antiserum to KGF was assessed in three ways. First, to assess specificity of the antiserum to KGF in tissue, sections of rat ventral prostate were incubated with either anti-KGF serum alone or antiserum that had been preincubated with $100 \mu \mathrm{g} / \mathrm{ml}$ recombinant human KGF. Preincubation of the antiserum with KGF was able to block nearly all staining in tissue sections (Fig. 1A), suggesting a minimal level of non-specific immunoreactivity.

Western blot analysis was also performed using samples of commercially prepared recombinant human FGF-1, -2 , $-4,-5,-6$ and -7 . As seen in Fig. 1B, only purified FGF-7 was recognized by the antiserum.

As a third test of specificity, Western blot analysis was performed on samples of whole prostate homogenate. As

Figure 2 Immunohistochemical analysis of KGF in the normal and androgen-manipulated rat ventral prostate. Sections of ventral prostate from normal or androgen-manipulated rats were stained for KGF protein as described in Materials and Methods. Representative fields from the three functional regions of the ductal system are presented (distal region, a, d, g, j, m, p; intermediate region, b, e, h, k, n, q; proximal region, c, f, i, l, o, r). In normal prostate (a, b, c), brown KGF staining was present mainly in the stromal cells (arrows). Day 4 postcastration ( $d, e, f)$, staining was reduced (arrows) and apoptotic epithelial cells were visible (arrowheads). Day 7 (g, h, i) and day 21 $(\mathrm{j}, \mathrm{k}, \mathrm{I})$ post-castration, stromal immunoreactivity returned (arrows). Day 21 castrate with $24 \mathrm{~h}$ DHT replacement therapy (m, n, o), strong epithelial immunoreactivity appeared in regions of epithelial regrowth (arrowheads) and persisted through $48 \mathrm{~h}$ of DHT replacement therapy $(p, q, r)$. Scale bar represents $50 \mu \mathrm{m}$. 

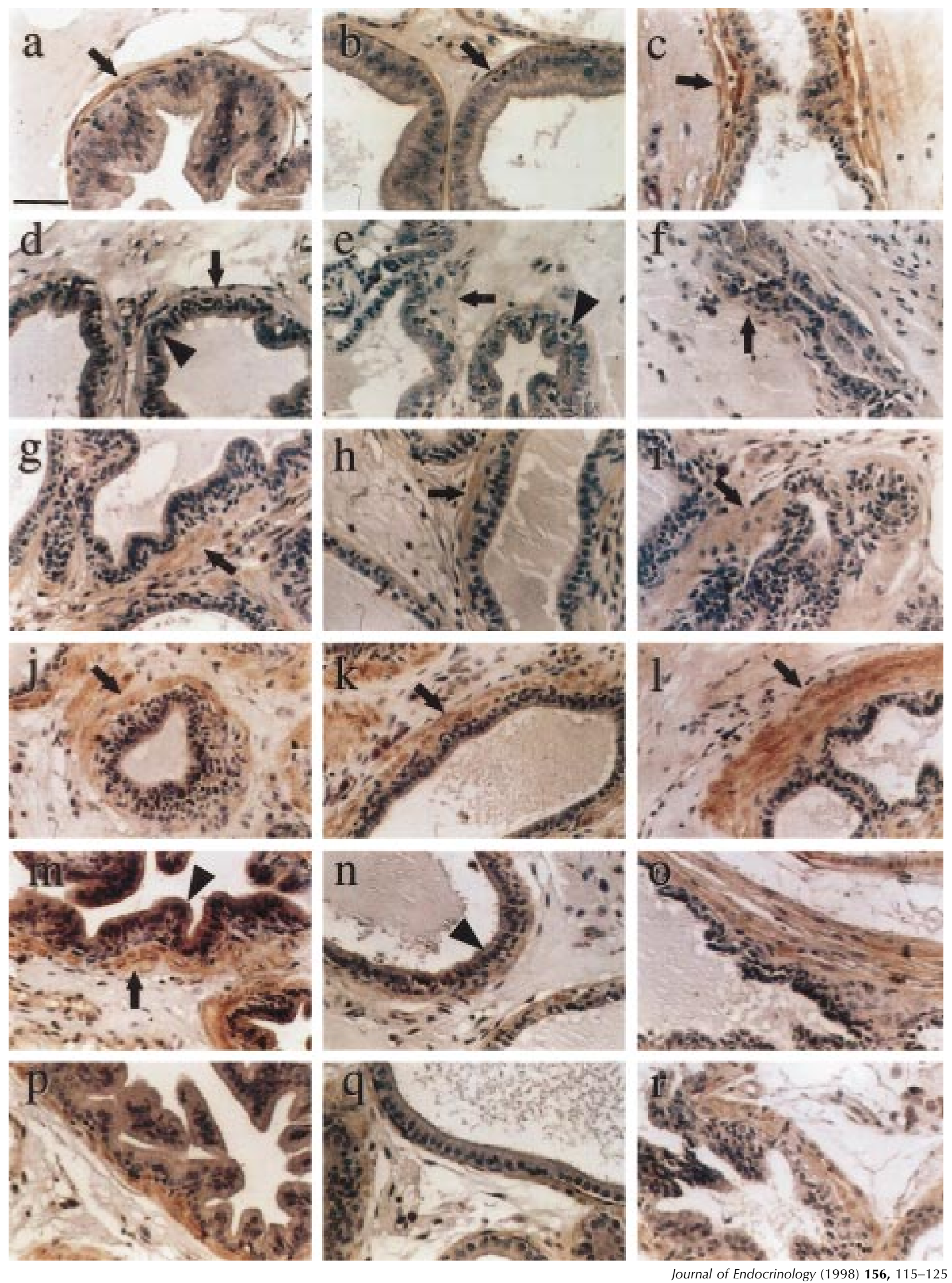
seen in Fig. 1C lane 1, the KGF antiserum recognized a single protein band with a molecular mass of $<21.4 \mathrm{kDa}$, corresponding to the approximate size of KGF. Lane 2, incubated with a control normal rabbit serum, showed only background staining. Amido black staining of a third duplicate lane (lane 3) confirmed efficient transfer of proteins to the membrane.

\section{Regional distribution of KGF along the prostatic duct}

Immunohistochemical techniques were used to examine the distribution of KGF among the three major functional regions of the normal prostatic ductal system. As seen in Fig. 2a, b and c (arrows), KGF immunoreactivity could be detected in the stroma directly adjacent to the epithelial cell layer, and appeared to reflect a mixture of intra- and extra-cellular localization. Specific association between KGF staining and either the smooth muscle or fibroblastic cells could not be determined. The presence of KGF protein in the ductal stroma was not related to any specific regional difference in epithelial cell function. Some faint immunoreactivity was also seen in the epithelium, and was most pronounced in the distal region of the duct.

\section{Persistence of KGF protein after androgen withdrawal and replacement}

To determine the effect of androgen removal on the pattern of KGF expression, sections of ventral prostates harvested at $0,4,7$ and 21 days post-castration were assessed by immunohistochemical examination for the presence of KGF protein. The effects of castration on prostate weight have been described previously, and supplementation of castrated animals with $2 \mathrm{~cm}$ lengths of DHT tubing has been shown to restore ventral prostates to control proportions (Lee et al. 1981). Prostate weights increased and decreased in response to androgen manipulation as expected (data not shown). By day 4 postcastration, immunoreactivity for KGF was greatly reduced in the stroma throughout the ductal system, and was barely detectable in the intermediate and proximal regions (Fig. 2d, e and f, arrows). The epithelium at this time was rapidly regressing, as demonstrated by the presence of numerous apoptotic cells in the distal and intermediate regions (Fig. 2d and e, arrowheads). By day 7, the involution process had slowed, and epithelial cell death had nearly stopped in the entire prostate (Fig. $2 \mathrm{~g}, \mathrm{~h}$ and i). KGF immunoreactivity had returned in the stroma at all levels of the ductal system (arrows) to a level similar to that seen at day 0. Likewise, the periductal stromal cells at day 21 were highly positive for KGF protein in all regions (Fig. 2j, k and l).

After androgen replacement for $24 \mathrm{~h}$, no change in stromal KGF staining could be seen (Fig. $2 \mathrm{~m}, \mathrm{n}$ and o); however, the epithelium in the distal region showed intense immunoreactivity (Fig. $2 \mathrm{~m}$, arrowhead), and some staining was also seen in the intermediate epithelium (Fig. 2n, arrowhead). After $48 \mathrm{~h}$ of androgen replacement, the KGF staining pattern returned to that seen at day 0 , with strong stromal immunoreactivity and faint staining in the epithelium throughout the ducts (Fig. 2p, q and r). Thus the loss of stromal KGF protein after androgen withdrawal was transient, and KGF returned in the absence of androgen. In addition, only epithelial staining for KGF was affected by androgen replacement.

\section{Separation of stromal and epithelial cell populations}

KGF and its receptor are expressed specifically by prostate stromal and epithelial cells respectively. Since the ratio of stromal and epithelial cells, and their respective products, changes dramatically in the prostate after castration, it was necessary to measure expression of these proteins by each cell type individually. Stromal and epithelial cell populations derived from normal or treated rat ventral prostates were separated using Percoll step gradients. The resulting cell samples had high viability as determined by trypan blue exclusion ( $>85 \%$ for all cell isolates). The identity and purity of the cell fractions was confirmed by immunocytochemical staining for cytokeratins 5 and 18 (Peehl et al. 1994). The epithelial cell fraction contained a mixture of luminal and basal cells, and contamination by nonepithelial cells was less than $1 \%$. Contamination of the stromal cell fraction by epithelial cells was also minimal (5-7\%). The separated epithelial and stromal cell fractions were used directly for RNA preparation and RT-PCR analysis to eliminate possible changes in protein expression due to culture conditions.

\section{KGF message levels during androgenic manipulation}

To assess further the possible effects of androgen on KGF expression, steady-state levels of KGF message were examined after androgen removal and replacement. RT-PCR analysis was performed on RNA samples prepared from isolated stromal cells, using primer pairs specific to the rat KGF or $\beta$-actin gene. As seen in Fig. 3A, the expected product of $392 \mathrm{bp}$ was amplified from all RNA samples. In the absence of reverse transcriptase, no product was observed, suggesting that the observed PCR product was not related to DNA contamination of RNA samples. The authenticity of the product was further confirmed by restriction digestion with BamHI (data not shown). As an internal control, similar reactions were carried out using primers specific to the rat $\beta$-actin gene. Again, a product of the expected size (764 bp) was observed in all samples (Fig. 3A). RT-PCR analysis was also performed on RNA samples from the epithelial cell fractions. No message for KGF was detected in any of the samples, confirming the lack of KGF expression by prostatic epithelial cells (data not shown). 

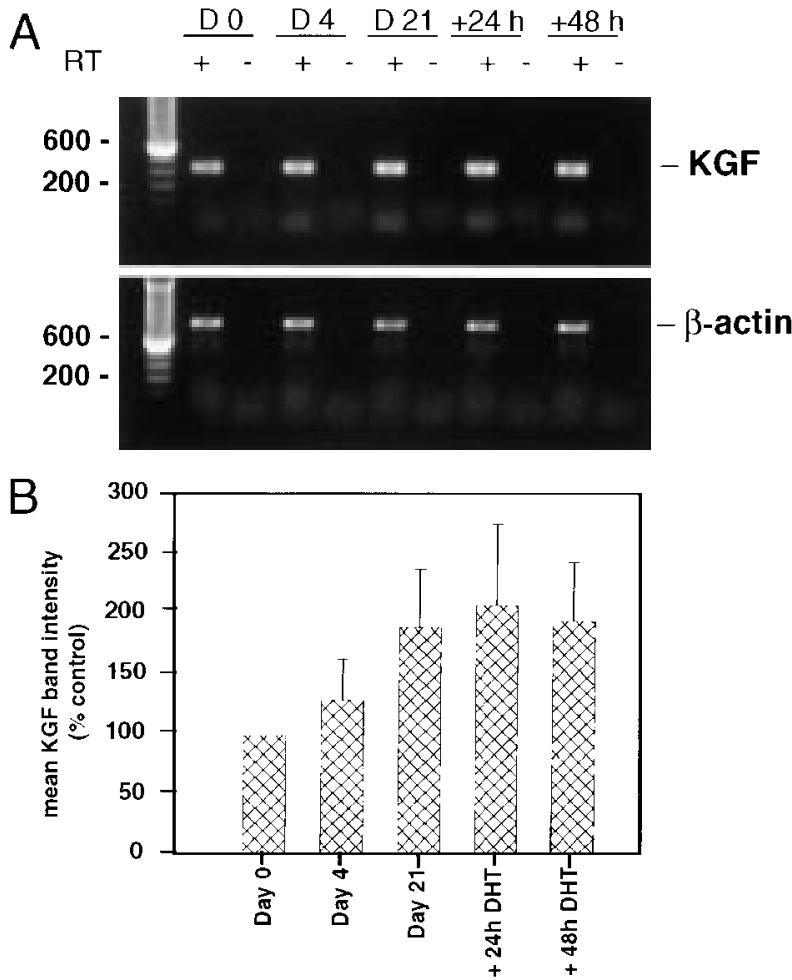

Figure 3 Effect of androgen withdrawal and replacement on KGF message levels in the rat ventral prostate. A, Prostate stromal cells were isolated from normal or androgen-manipulated rats as described in Materials and Methods. RT-PCR analysis was performed, in the presence $(+)$ or absence $(-)$ of reverse transcriptase, on RNA samples prepared from isolated prostate stromal cells using primers specific to rat KGF or $\beta$-actin. Products were separated by agarose gel electrophoresis, visualized by ethidium bromide staining, and measured by scanning densitometry. B, Values for KGF message were normalized to $\beta$-actin control, and plotted as percentage of day 0 control $(n=3$, mean \pm S.D.). KGF message levels did not vary significantly from control after any treatment $(P>0 \cdot 05)$.

For purposes of comparison, we then determined the range of linearity with regard to the number of PCR amplification cycles and amount of input RNA (data not shown). We chose 26 cycles and 750 ng of RNA sample for all subsequent experiments, since these conditions were within the linear range of amplification for both the KGF and $\beta$-actin primer sets. After scanning photographs of the ethidium bromide-stained gels, band intensities for KGF products were normalized to their $\beta$-actin counterparts, and the mean values of three experiments were plotted as percentages of day 0 control (Fig. 3B). Although this method was not strictly quantitative, we observed that KGF message persisted at a high level after castration, and was abundant even at 21 days post-castration (Fig. 3B). Androgen replacement for 24 or $48 \mathrm{~h}$ also had no significant effect on the steady-state level of KGF message. The high level of KGF message observed on day 4 post- castration also suggests that the diminished immunoreactivity for KGF seen in Fig. 2d, e and $\mathrm{f}$ was not related to loss of the KGF transcript.

\section{KGF expression in immature prostate}

Previous studies have demonstrated the importance of KGF in the androgen-induced growth of seminal vesicle and prostate in organ culture, using fetal or newborn tissues (Alarid et al. 1994, Sugimura et al. 1996). To address the possibility that KGF expression may be regulated differently in immature versus adult rat prostate, immunohistochemical and RT-PCR analyses described above were performed on prostate tissue from 14-day-old newborn rats or 14-day-old rats that had been castrated on day 5 after birth. As seen in Fig. 4a, KGF protein could be detected in stromal cells surrounding the developing ducts (arrow). Strong stromal immunoreactivity could still be observed in neonatally castrated rat prostate tissue (Fig. 4b, arrow), suggesting that KGF was still being expressed in the absence of androgen. In contrast with the stromal staining, a striking difference was seen in the epithelial KGF immunoreactivity. KGF protein was high in the rapidly growing ductal epithelium of the normal neonatal prostate (Fig. 4a, arrowhead); however, the epithelium in the prostate of the castrated neonate was nearly devoid of staining for KGF (Fig. 4b, arrowhead). Therefore, as seen in the adult, only epithelial staining for KGF was affected by androgen status in the neonatal prostate.

Steady-state levels of KGF message were also compared in prostates from normal and castrated neonates. Using the comparative RT-PCR method as described above, KGF message could be detected in samples from both normal and castrated neonatal rats (Fig. 5A), and no significant difference was found in KGF message levels between the two samples in comparison with the $\beta$-actin control (Fig. 5B). Taken together, these data support the hypothesis that KGF expression is not positively regulated by androgen in the rat prostate in vivo.

\section{Discussion}

The results of the present study reveal that production of KGF by prostatic stromal cells was not greatly influenced by androgen status in vivo. According to the hypothesis that KGF is an andromedin (Yan et al. 1992), a decrease in KGF expression would be expected after androgen removal; however, we observed no significant decrease in KGF message or protein after androgen manipulation. This result is consistent with previous reports by Sugimura et al. (1996), who saw continued presence of the KGF message in the prostate after castration, and by Nishi et al. (1996), who also did not see a decrease in KGF message after castration, but actually observed a large induction of KGF message. This induction of KGF message may have 


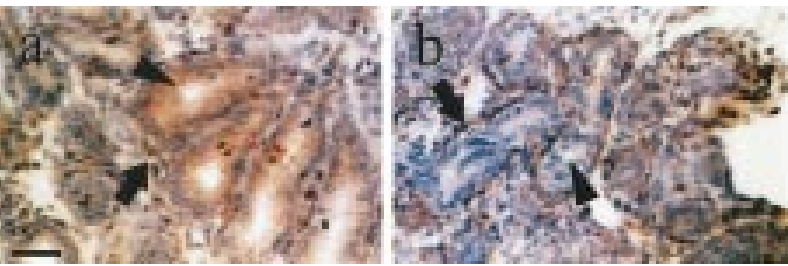

Figure 4 Immunohistochemical analysis of prostatic KGF in the normal and castrated neonatal rat. Sections of ventral prostate from normal or 10-day castrated neonatal rats were stained for KGF protein as described in Materials and Methods. In the normal day 14 rat prostate (a), KGF immunoreactivity was seen in the stromal cells (arrow), as well as in the rapidly growing epithelium (arrowhead). In the prostate of the castrated neonate (b), stromal immunoreactivity was present (arrow), but epithelial staining was absent (arrowhead). Scale bar represents $50 \mu \mathrm{m}$.

been related to a relative increase in stromally derived mRNAs after castration, since most of the prostatic epithelium is lost as the result of active cell death after androgen removal (Coffey et al. 1968), thus greatly increasing the relative proportion of stromal cells in the prostate. Problems resulting from changing cell ratios were minimized in the present study by separating the stromal and epithelial cell fractions before measurement of KGF message.

Our present observations are not surprising in view of mounting evidence suggesting that regulation of $\mathrm{KGF}$ expression may be highly complex, involving a number of inductive and inhibitory factors. Yan et al. (1992) have demonstrated increased KGF expression by prostate stromal cultures in response to androgen, and Fasciana et al. (1996) have found an androgen-inducible element in the KGF promoter. In addition, interleukin- $\alpha 1$, plateletderived growth factor-BB and transforming growth factor- $\alpha$ have all been shown to stimulate KGF production by human fibroblasts, while neither basic FGF nor tumor necrosis factor- $\alpha$ had any significant effect (Chedid et al. 1994). On the other hand, KGF synthesis could be inhibited in human fibroblasts by glucocorticoids such as dexamethasone or hydrocortisone (Chedid et al. 1996). Koji et al. (1994) have also found that KGF expression was sensitive to progesterone in the primate endometrium; however, this response was limited to stromal smooth muscle cells in the basalis region, and KGF expression was independent of progesterone in smooth muscle cells of the myometrium. Although KGF expression may be responsive to a number of factors individually in a culture, the interaction of these various factors within an animal may have a very different effect, and the reaction to a specific factor may vary between cell types in the same tissue. Further studies on intact prostates may provide insights into KGF regulatory mechanisms in vivo.

The results of our immunohistochemical experiments show a transient loss of KGF immunostaining on day 4 after castration (Fig. 2d, e and f), which was most likely
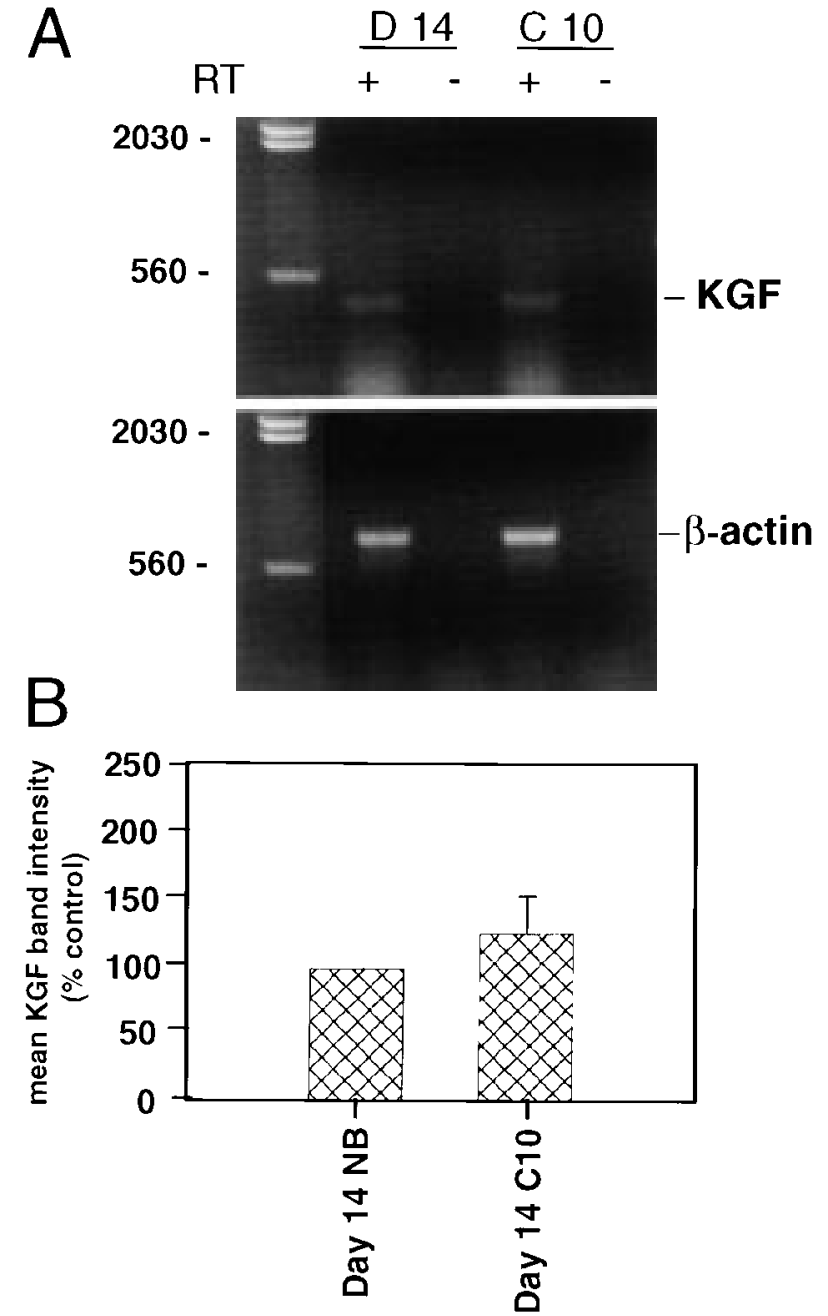

Figure 5 Effect of androgen withdrawal on KGF message levels in the immature rat ventral prostate. A, Ventral prostates were isolated from normal (D 14) or castrated (C 10) neonatal rats as described in Materials and Methods. RT-PCR analysis was performed, in the presence $(+)$ or absence $(-)$ of reverse transcriptase, on RNA samples prepared from the prostates using primers specific to rat KGF or $\beta$-actin. Products were separated by agarose gel electrophoresis, visualized by ethidium bromide staining, and measured by scanning densitometry. B, Values for KGF message were normalized to $\beta$-actin control, and plotted as percentage of day 0 control $(n=3$, mean \pm S.D. $)$. KGF message levels did not vary significantly from control after castration $(P>0 \cdot 05)$.

due to proteolytic degradation of extracellular matrix (ECM)-associated pools of the protein. After castration, there is a massive induction of ECM-modifying enzyme activity in the prostate, including cathepsins (Lee et al. 1990), urokinase (Andreasen et al. 1990, Wilson et al. 1996), gelatinases (Wilson et al. 1991) and collagenases (see Guenette \& Tenniswood (1994) for a review). A number of these enzymes have also been shown to be involved in 
the release of matrix-bound members of the FGF family, such as plasmin (Saksela \& Rifkin 1990) and heparitinase (Bashkin et al. 1989). So it is possible that the KGF protein is lost or destroyed as a result of rapid matrix turnover during involution, and reappears once matrix degradation has slowed by day 7 . Post-transcriptional changes could also explain the loss of KGF protein despite the presence of abundant message. Such a mechanism is unlikely though, since immunoreactive KGF protein was fully restored after regression had ceased, without any change in androgen status.

Surprisingly, we observed the most dramatic change in KGF immunostaining in the prostate epithelium, where high levels of the protein were seen in the rapidly growing epithelium of the neonate (Fig. 4a) and in the castrated adult in response to androgen replacement (Fig. 2m). This staining is probably not due to expression by the epithelium, as KGF has been demonstrated to be produced solely by stromal cells in normal prostate (Yan et al. 1992, Story et al. 1997), and we were unable to detect KGF message in our isolated epithelial cell fractions. It is possible that the epithelial localization of KGF is related to detection of internalized ligand after receptor activation, which has been clearly demonstrated for other members of the FGF family. For example, FGF-2 has been shown to accumulate intracellularly in bovine endothelial cells, both within the nucleolus (Bouche et al. 1987) and in lysosomal compartments (Moscatelli 1988), where it is then degraded slowly with an apparent half-life of $8 \mathrm{~h}$. Likewise, exogenous FGF-1 has been found to accumulate in the cytoplasm and associate with the nucleus by a receptor-dependent mechanism (Zhan et al. 1993, Prudovsky et al. 1994). So it is plausible that receptormediated internalization of stromally derived KGF could result in the intracellular accumulation of KGF protein in regions of rapid epithelial cell growth. Further investigation into the intracellular fate of KGF is needed to understand this mechanism fully.

It is clear that KGF action is important to the androgeninduced growth and development of the prostate. In organ culture studies, it has been found that antibody neutralization of KGF activity could inhibit growth and branching morphogenesis of prostatic buds in response to androgen, and that KGF could actually stimulate ductal growth in the absence of androgen (Sugimura et al. 1996). Recently a KGF knockout mouse was described (Guo et al. 1996). Upon examination of the ventral prostate, no gross histologic abnormalities were detected; however, closer examination may reveal subtle anomalies in epithelial function or ductal structure. Certainly it is possible that other members of the FGF family may have compensated somewhat for the lack of KGF, as FGF-1 can bind to the KGF receptor with high affinity (Miki et al. 1992, Wang et al. 1995), but certain specific effects unique to KGF may also exist which are important for normal morphogenesis or differentiated function.
Although our results indicate that KGF production is not androgen-responsive in vivo in the prostate, its mitogenic activity clearly is, as evidenced by the organ culture experiments of Sugimura et al. (1996). FGFs, including KGF, are stored in complex with heparincontaining matrix and cell-surface molecules, and it is thought that the matrix association of the FGF molecule must be modified to allow the factor to interact with its cellular receptor and produce a signal (Bashkin et al. 1989). It is possible that this modification process is under androgenic control in the prostate, perhaps through local elaboration of specific matrix-modifying enzymes. It has already been noted that numerous ECM-modifying enzymes are induced during prostate regression (Wilson et al. 1991, 1996), and modification of the ECM is intimately involved in the processes of growth and morphogenesis (Fukada et al. 1988, Brenner et al. 1989, Behrendsten et al. 1992). This mechanism of KGF regulation by androgen could be consistent with the observations of Sugimura et al. (1996), and may be at least partially responsible for those of Yan et al. (1992), who observed increased KGF activity in response to androgen in prostatic fibroblast cultures. This release mechanism could also help clarify the apparent paradox regarding the distribution of KGF protein in the ductal system. In the present study we observed that KGF protein was present at high levels in the stroma throughout the ductal system. Epithelial staining for KGF, presumably resulting from internalization of the activated receptor-ligand complex (Moscatelli 1988, Prudovsky et al. 1994), was consistently associated with regions of epithelial proliferation, such as the distal segment in the adult and the normal newborn rat prostate. Further investigation into the mechanisms governing the release and presentation of KGF to its receptor is clearly warranted.

\section{Acknowledgement}

This work was supported in part by NIH grants DK47561, HD28048 and DK07706, and the American Foundation for Urologic Disease.

\section{References}

Alarid ET, Rubin JS, Young P, Chedid M, Ron D, Aaronson SA \& Cunha GR 1994 Keratinocyte growth factor functions in epithelial induction during seminal vesicle development. Proceedings of the National Academy of Sciences of the USA 91 1074-1078.

Andreasen PA, Kristensen P, Lund LR \& Dano K 1990 Urokinasetype plasminogen activator is increased in the involuting ventral prostate of castrated rats. Endocrinology 126 2567-2576.

Bashkin P, Doctrow S, Klagsbrun M, Svahn CM, Folkman J \& Vlodavsky I 1989 Basic fibroblast growth factor binds to subendothelial extracellular matrix and is released by heparitinase and heparin-like molecules. Biochemistry 28 1737-1743.

Behrendsten O, Alexander CM \& Werb Z 1992 Metalloproteinases mediated extracellar degradation by cells from mouse blastocyst outgrowths. Development 114 447-456. 
Bouche G, Gas N, Prats H, Baldin V, Tauber J, Teissie J \& Amalric F 1987 Basic fibroblast growth factor enters the nucleolus and stimulates the transcription of ribosomal genes in ABAE cells undergoing G0-G1 transition. Proceedings of the National Academy of Sciences of the USA 84 6770-6774.

Brenner CA, Adler RR, Rappolee DA, Pederson RA \& Werb Z 1989 Genes for extracellular matrix-degrading metalloproteinases and their inhibitor, TIMP, are expressed during early mammalian development. Genes and Development 3 848-859.

Camp TA, Rahal JO \& Mayo KE 1991 Cellular localization and hormonal regulation of follicle-stimulating hormone and luteinizing hormone receptor messenger RNAs in the rat ovary. Molecular Endocrinology 5 1405-1417.

Chang S-M \& Chung LWK 1989 Interaction between prostatic fibroblasts and epithelial cells in culture: role of androgen. Endocrinology 125 2719-2727.

Chedid M, Rubin JS, Csaky KG \& Aaronson SA 1994 Regulation of keratinocyte growth factor gene expression by interleukin-1. Journal of Biological Chemistry 269 10753-10757.

Chedid M, Hoyle JR, Csaky KG \& Rubin JS 1996 Glucocorticoids inhibit keratinocyte growth factor production in primary dermal fibroblasts. Endocrinology 137 2232-2237.

Coffey DS, Shimazaki J \& Williams-Ashman HG 1968 Polymerization of deoxyribonucleotides in relation to androgen-induced prostatic growth. Archives of Biochemistry and Biophysics 124 184-198.

Cunha GR \& Chung LWK 1981 Stromal-epithelial interactions. I. Induction of prostatic phenotype in urothelium of testicular feminized (Tfm/y) mice. Journal of Steroid Biochemistry and Molecular Biology 14 1317-1321.

Cunha GR, Shannon JM, Newbauer BL, Sawyer LM, Fuji H, Taguchi O \& Chung LWK 1981 Mesenchymal-epithelial interactions in sex differentiation. Human Genetics 56 68-77.

Cunha GR, Chung LWK, Shannon JM, Taguchi O \& Fujii H 1983 Hormone-induced morphogenesis and growth: role of mesenchymal-epithelial interactions. Recent Progress in Hormone Research 39 559-598.

Fasciana C, van der Made AC, Faber PW \& Trapman J 1996 Androgen regulation of the rat keratinocyte growth factor (KGF/FGF7) promoter. Biochemical and Biophysical Research Communications 220 858-863.

Fukada Y, Masuda Y, Kishi J, Hashimoto Y, Hayakawa T \& Nogawa H 1988 The role of interstitial collagens in cleft formation of mouse embryonic submandibular gland formation during initial branching. Development 103 259-267.

Guenette RS \& Tenniswood M 1994 The role of growth factors in the suppression of active cell death in the prostate: an hypothesis. Biochemistry and Cell Biology 72 553-559.

Guo L, Degenstein L \& Fuchs E 1996 Keratinocyte growth factor is required for hair development but not for wound healing. Genes and Development 10 165-175.

Isaacs J 1984 Antagonistic effect of androgen on prostatic cell death. Prostate 5 545-557.

Kerr JFR \& Searle J 1973 Deletion of cells by apoptosis during castration-induced involution of the rat prostate. Virchows Archiv. B. Cell Pathology 13 87-102.

Koji T, Chedid M, Rubin JS, Slayden OD, Csaky KG, Aaronson SA \& Brenner RM 1994 Progesterone-dependent expression of keratinocyte growth factor mRNA in stromal cells of the primate endometrium: keratinocyte growth factor as a progestomedin. Journal of Cellular Biology 125 393-401.

Laemmli UK 1970 Cleavage of structural proteins during the assembly of the head of bacteriophage T4. Nature 227 680-685.

Lee C, Prins GS, Henneberry MO \& Grayhack JT 1981 Effect of estradiol on the rat prostate in the presence and absence of testosterone and pituitary. Journal of Andrology 2 293-299.

Lee C, Sensibar JA, Dudek SM, Hiipakka RA \& Liao S 1990 Prostatic ductal system in rats: regional variation in morphological and functional activities. Biology of Reproduction 43 1079-1086.
Lee C, Goolsby CL \& Sensibar JA 1994 Cell cycle kinetics in rat prostatic epithelia: nuclear migration during G2 phase. Journal of Urology 152 2294-2299.

McKeehan WL, Adams PS \& Rosser MP 1984 Direct mitogenic effects of insulin, epidermal growth factor, glucocorticoid, cholera toxin, unknown pituitary factors, and possibly prolactin, but not androgen on normal rat prostatic epithelial cells in serum-free, primary culture. Cancer Research 44 1998-2010.

Miki T, Bottaro DP, Fleming TP, Smith CL, Burgess WH, Chan AM-L \& Aaronson SA 1992 Determination of ligand-binding specificity by alternative splicing: two distinct growth factor receptors encoded by a single gene. Proceedings of the National Academy of Sciences of the USA 89 246-250.

Montpetit ML \& Tenniswood MP 1989 Separation of mature rat ventral prostate epithelial and fibroblast cells. Prostate 15 315-325.

Moscatelli D 1988 Metabolism of receptor-bound and matrix-bound basic fibroblast growth factor by bovine capillary endothelial cells. Journal of Cellular Biology 107 753-759.

Nemeth JA \& Lee C 1996 Prostatic ductal system in rats: regional variation in stromal organization. Prostate 28 124-128.

Nishi N, Oya H, Matsumoto K, Nakamura T, Miyanaka H \& Wada F 1996 Changes in gene expression of growth factors and their receptors during castration-induced involution and androgeninduced regrowth of rat prostates. Prostate 28 139-152.

Peehl DM, Leung GK \& Wong ST 1994 Keratin expression: a measure of phenotypic modulation of human prostatic epithelial cells by growth inhibitory factors. Cell and Tissue Research $\mathbf{2 7 7}$ $11-18$.

Prins GS, Birch L \& Greene GL 1991 Androgen receptor localization in different cell types of the adult rat prostate. Endocrinology 129 3187-3199.

Prins GS, Cooke PS, Birch L, Donjacour AA, Yalcinkaya TM, Siiteri PK \& Cunha GR 1992 Androgen receptor expression and $5 \alpha$-reductase activity along the proximal-distal axis of the rat prostatic duct. Endocrinology 130 3066-3073.

Prudovsky I, Savion N, Zhan X, Friesel R, Xu J, Hou J, McKeehan WL \& Maciag T 1994 Intact and functional fibroblast growth factor (FGF) receptor-1 trafficks near the nucleus in response to FGF-1. Journal of Biological Chemistry 269 31720-31724.

Rubin JS, Bottaro DP, Chedid M, Miki T, Ron D, Cheon H-G, Taylor WG, Fortney E, Sakata H, Finch PW \& LaRochelle WJ 1995 Keratinocyte growth factor. Cell Biology International 19 399-411.

Saksela O \& Rifkin DB 1990 Release of basic fibroblast growth factor-heparan sulfate complexes from endothelial cells by plasminogen activator-mediated proteolytic activity. Journal of Cellular Biology 110 767-775.

Story MT, Hopp KA, Molter M \& Meier DA 1994 Characteristics of FGF-receptors expressed by stromal and epithelial cells cultured from normal and hyperplastic prostates. Growth Factors 10 269-280.

Story MT, Hopp KA, Meier DA, Haq R-U \& Rosen MA 1997 Expression of keratinocyte growth factor (FGF7) mRNA and secretion of the protein by human prostate stromal cells. Prostate (In Press).

Sugimura Y, Cunha GR, Donjacour AA, Bigsby RM \& Brody JR 1986 Whole-mount autoradiography study of DNA synthetic activity during postnatal development and androgen-induced regeneration in the mouse prostate. Biology of Reproduction 34 985-995.

Sugimura Y, Foster BA, Hom YK, Lipschutz JH, Rubin JS, Finch PW, Aaronson SA, Hayashi N, Kawamura J \& Cunha GR 1996 Keratinocyte growth factor (KGF) can replace testosterone in the ductal branching morphogenesis of the rat ventral prostate. International Journal of Developmental Biology 40 941-951.

Tenniswood M 1986 Role of epithelial-stromal interactions in the control of gene expression in the prostate: an hypothesis. Prostate 9 $375-385$. 
Wang F, Kan M, Xu J, Yan G \& McKeehan WL 1995 Ligand-specific structural domains in the fibroblast growth factor receptor. Journal of Biological Chemistry 270 10222-10230.

Wilson MJ, Strasser M, Vogel MM \& Sinha AA 1991

Calcium-dependent and calcium-independent gelatinolytic proteinase activities of the rat ventral prostate and its secretion: characterization and effect of castration and testosterone treatment. Biology of Reproduction 44 776-785.

Wilson MJ, Ludowese C, Sinha AA \& Estensen RD 1996 Effects of castration on plasminogen activator activities and plasminogen activator inhibitor type I in the rat ventral prostate. Prostate $\mathbf{2 8}$ 239-250.
Yan G, Fukabori Y, Nikolaropoulos S, Wang S \& McKeehan WL 1992 Heparin-binding keratinocyte growth factor is a candidate stromal to epithelial cell andromedin. Molecular Endocrinology 6 2123-2128.

Zhan X, Hu X, Friesel R \& Maciag T 1993 Long term growth factor exposure and differential tyrosine phosphorylation are required for DNA synthesis in BALB/c 3T3 cells. Journal of Biological Chemistry 268 9611-9620.

Received 4 March 1997

Revised manuscript received 30 June 1997

Accepted 26 August 1997 